引用格式:盖美,朱静敏,孙才志, 等. 中国沿海地区海洋经济效率时空演化及影响因素分析 [J]. 资源科学, 2018,40(10): 19661979. [Gai M, Zhu J M, Sun C Z, et al. Spatio-temporal evolution and influencing factors of marine economic efficiency in coastal areas of China[J]. Resources Science, 2018,40(10): 1966-1979.] DOI :10.18402/resci.2018.10.06

\title{
中国沿海地区海洋经济效率时空演化 及影响因素分析
}

\author{
盖 美,朱静敏,孙才志,孙 康
}

(辽宁师范大学海洋经济与可持续发展研究中心, 大连 116029)

\begin{abstract}
摘 要: 为展现中国沿海地区海洋经济效率时空演变现状,并根据其具体原因提出针对性对策建议,促进中国 海洋经济可持续发展, 本文基于考虑非期望产出的三阶段超效率SBM-Global模型、标准差椭圆和重心坐标方法, 对中国沿海11 个省市2000-2015 年海洋经济效率进行测算和时空对比分析。研究发现: (1) 与一阶段相比, 三阶段 海洋经济效率整体上升, 各省市排名出现不同程度变动; (2)时间演变上,全国各沿海地区海洋经济效率呈上升趋 势,绝对差异和相对差异都不断变大; (3)空间演变上,全国标准差椭圆呈东北一西南格局分布,面积由小变大,效率 分布由收缩趋势变为分散趋势, 最终呈北、中、南三级格局分布, 与三大海洋经济圈分布相吻合; 三大海洋经济圈标 准差椭圆面积都逐渐缩小, 效率分布出现极化现象; (4)海洋经济区位謫、海洋科研人力资本、海洋环保技术水平与 海洋经济效率之间存在非线性关系; 陆域经济发展水平、海洋产业结构水平、政府对海洋科技支持力度、海洋经济 政策力度对海洋经济效率呈显著正影响; 对外开放水平对其影响不显著。
\end{abstract}

关键词: 海洋经济效率; 三阶段超效率SBM-Global; 标准差椭圆; 重心转移; 面板门槛模型; 沿海地区; 中国

DOI :10.18402/resci.2018.10.06

\section{1 引言}

21 世纪是海洋世纪, 随着陆域资源、能源和空 间压力与日俱增, 海洋已经成为世界各国提高综合 国力和争夺长远战略优势的新领域。20世纪 90 年 代以来, 中国海洋经济年均增速持续高于同期国民 生产总值, 2017 年海洋 GDP 达 77611 亿元, 占国民 经济比重的 $9.4 \%{ }^{[1]}$, 但海洋经济效率提高却日益受 发展方式粗放、废弃物增多、环境污染严重等因素 制约 ${ }^{[2]}$ 。在国家大力提倡“发展海洋强国”、“一带一 路”背景下, 《全国海洋经济发展“十三五”规划》的指 出必须改变过去粗放、不计环境后果的经济发展方 式, 促进海洋经济可持续发展。因此本文从资源、 环境、经济三方面研究海洋经济投人产出关系, 掌
握海洋经济发展优势与不足, 对扭转长期以来海洋 经济“高投人,低产出”局面, 提高海洋经济效率具 有重要参考意义。

国内外有关研究主要分为以下两类: (1) 某一部 门或产业方面。渔业效率方面, Tingley 等利用 SFA 和传统 DEA 模型对英吉利海峡渔业技术效率及其 影响因素进行测算分析 ${ }^{[4]}$; 卢昆等对中国 6 个远洋渔 业主产省份进行随机前沿分析 ${ }^{[5]}$ 。海洋交通效率方 面, Odeck 等运用 DEA 和 SFA 模型研究亚洲、欧洲 和非洲海洋运输效率, 分析三个区域之间差异并比 较两种模型优劣 ${ }^{[6]}$; 于谨凯等利用超效率 DEA 模型 对中国 11 个沿海省市海洋交通运输业效率进行分

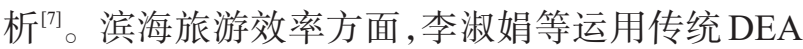

收稿日期: 2018-04-17, 修订日期: 2018-09-10

基金项目: 教育部人文社会科学重点研究基地重大项目(16JJD790021); 国家社会科学基金重大项目(14ZDB130); 辽宁省社科规划基金项目 (L18BTJ002)。

作者简介:盖美,女,辽宁大连人,博士,教授,主要从事区域经济与可持续发展方面的研究。E-mail: gaimei71@163.com

通讯作者:朱静敏,E-mail: 1527653583@qq.com

http://www.resci.cn 
测算山东蓝色经济区旅游效率和全要素生产率 ${ }^{[8]}$; 钟敬秋等在 DEA 基础上结合椭圆分析法对中国沿 海 53 个沿海城市旅游业效率进行时空演变分析 ${ }^{[0]}$ 。 (2) 海洋经济整体效率。Ding 等运用改进的三阶段 DEA 模型测度了包含资源投人和环境产出的海洋 经济绿色效率,而后分析海洋经济绿色效率的变化 ${ }^{[10]}$; 范斐等利用传统 DEA 模型对环渤海 17 个沿海城市 的海洋经济效率进行评估 ${ }^{[11]}$; 赵林等基于非期望产 出的 SBM 模型对中国海洋经济效率进行测评 ${ }^{[12]}$ 。

纵观已有文献, 国外研究主要集中于海洋经济 的某一部门或产业的经济效率方面, 在整体效率上 研究不足; 国内研究起步较晚, 关于海洋经济部门 或整体效率的文献数量较少。在研究方法上, 以数 据包络分析 (DEA) 和随机前沿分析 (SFA) 为主, 虽 然方法相对成熟, 但缺乏对外部环境因素和随机误 差影响方面的考虑, 导致效率测算结果与实际尚有 一定偏差。在研究区域范围方面, 虽然有少数关于 中国沿海 11 个省市的海洋经济效率研究, 但在此基 础上, 基于国家海洋经济规划中三大海洋经济圈并 以此展开的研究尚未发现。三大海洋经济圈在中 国海洋经济发展中有举足轻重的地位, 有必要对这 些区域展开更为深人研究。在研究内容方面, 国内 外文献中还存在忽略海洋经济效率时空动态演变 分析的不足。

为弥补已有文献中存在的不足, 本文以中国沿 海 11 个省市为研究对象, 运用考虑非期望产出的三 阶段超效率SBM-Global模型(基于全局参比法)、标 准差椭圆和重心坐标法对海洋经济效率进行时空 演化分析, 最后对海洋经济效率影响因素进行测算 分析。本文的主要优势表现在:

(1) 采用全局参比法 (SBM-Global), 所有决策 单元参照同一前沿面计算与前沿面距离, 结果更具 可比性; 基于非期望产出的超效率 SBM-Global 模型 在克服传统 DEA 投人产出松弛性问题基础上, 有效 单元效率值可大于 1 , 可对有效单元进行比较分析; 考虑非期望产出可解决存在 “坏”产出时的效率评 价问题, 使效率结果更加符合实际, 也更加符合现 阶段注重“发展的环境代价”的时代主题。

(2) 三阶段超效率SBM-Global 模型剔除外部环 境因素和随机误差对投人变量的影响,避免各地区
因面临不同外在环境因素和随机噪声而造成不必 要误差,计算结果更能反映实际海洋经济发展的优 势与不足。

(3) 从多重角度定量识别并以空间可视化方式 精细刻画中国沿海 11 个省市 2000-2015 年海洋经 济效率的全局及局部分布特征和动态演化特征。

(4)分析海洋经济效率影响因素,这对于理清 海洋经济效率的时空演化特征及其影响因素机制, 并根据各省份实际状况提出针对性意见,具有重要 的理论和现实意义。

\section{2 研究方法与数据来源}

\section{1 研究方法}

2.1.1 基于非期望产出的三阶段超效率 SBM-Global 模型

三阶段 DEA 模型由 Fried 等提出 ${ }^{[13]}$, 该模型最 大优势是可有效剔除外部环境因素和随机误差等 不可控因素的影响,更准确地评估效率。本文将三 阶段 DEA 中第一阶段改进为基于非期望产出的超 效率SBM-Global模型(投人导向),三阶段同样采用 投人导向 SBM-Global模型。其模型构建如下:

第一阶段:超效率SBM-Global模型。

Tone 提出基于松弛变量 (Slacks-based Measure) 的超效率 SBM 模型 ${ }^{[14]}$, 当决策单元无效时, 结 果与标准效率模型一致,决策单元有效时,效率值 可超过 1 。本文将非期望产出引人模型。公式如下：

$$
\begin{gathered}
\min \rho=\frac{\frac{1}{m} \sum_{i=1}^{m} \frac{\bar{x}}{x_{i k}}}{\frac{1}{r_{1}+r_{2}}\left(\sum_{s=1}^{r_{1}} \frac{\overline{y^{d}}}{y_{s k}^{d}}+\sum_{q=1}^{r_{1}} \overline{\overline{y^{u}}} \frac{\overline{y_{q k}^{u}}}{u}\right)} \\
\text { s.t. } \quad \bar{x} \geqslant \sum_{j=1, \neq k}^{r_{1}} x_{i j} \lambda_{j} \quad(i=1,2, \cdots, m) \\
\overline{y^{d}} \leqslant \sum_{j=1, \neq k}^{n} y_{s j}^{d} \lambda_{j} \quad\left(s=1,2, \cdots, r_{1}\right) \\
\overline{y^{d}} \geqslant \sum_{j=1, \neq k}^{n} y_{q j}^{b} \lambda_{j} \quad\left(q=1,2, \cdots, r_{2}\right) \\
\lambda_{j}>0 \quad(j=1,2, \cdots, n ; j \neq 0) \\
\bar{x} \geqslant x_{k} \quad(i=1,2, \cdots, m) \\
\overline{y^{d}} \leqslant y_{k}^{d} \quad\left(s=1,2, \cdots, r_{1}\right) \\
\overline{y^{u}} \geqslant y_{k}^{u} \quad\left(q=1,2, \cdots, r_{2}\right)
\end{gathered}
$$

式中 $\rho$ 为海洋经济效率值 $(\rho \geqslant 1$ 且圥余为 0 时 DMU 
完全有效) $; n$ 为决策单元 (DMU) 数量; $m 、 r_{1}$ 和 $r_{2}$ 分 别为投人、期望产出和非期望产出个数; $s=\left(\bar{x}, \overline{y^{d}}\right.$, $\left.\overline{y^{u}}\right)$ 表示投人、期望产出和非期望产出冗余量; $\lambda$ 为 权重向量。参考马占新研究并根据本文研究实际 ${ }^{[15]}$, 定义 $\rho<0.6$ 为无效; $0.6 \leqslant \rho<0.8$ 为效率中等; $0.8 \leqslant \rho<1$ 为效率良好; $\rho \geqslant 1$ 为高效率。

第二阶段:相似 SFA 模型。

在“固定产出, 投人最小化” 原则下, 以第一阶 段各决策单元投人指标的圥余量为因变量, 外在环 境因素、随机因素和管理因素为自变量, 构建相似 SFA 模型,其表达式如下:

$$
S_{n i}=f^{n}\left(Z_{i} ; \beta^{n}\right)+V_{n i}+U_{n i}
$$

式中 $S_{n i}$ 为第 $i$ 个决策单元在第 $n$ 个投人上的松驰变 量; $Z_{i}=\left(Z_{1 i}, Z_{2 i}, \cdots, Z_{k i}\right)$ 为 $k$ 维环境变量; $\beta^{n}$ 为环境变 量对应参数向量; $V_{n i}+U_{n i}$ 为联合误差项 $\varepsilon_{i} ; U_{n i}$ 为随机 误差, 呈截断分布; $V_{n i}$ 表示管理无效率, 呈正态分 布; $U_{n i}$ 和 $V_{n i}$ 独立不相关 ${ }^{[16]}$ 。通过最大似然估计, 算 出各参数值, 并代人以下调整公式, 得出同质环境 下的新投人值:

$$
\begin{aligned}
X_{n i}^{*} & =X_{n i}+\left[\max \left(Z_{i} \beta^{n}\right)-Z_{i} \beta^{n}\right]+\left[\max \left(V_{n i}\right)-V_{n i}\right] \\
(n & =1,2, \cdots, N ; i=1,2, \cdots, I)
\end{aligned}
$$

式中 $X_{n i}^{*}$ 为调整后投人; $X_{n i}$ 为原始投人; $\max \left(Z_{i} \beta^{n}\right)$ 表示最差环境条件, 其它决策单元都以此为基础进 行调整; $V_{n i}$ 随机误差调整原理同上。

第三阶段: 调整投人后的超效率 SBM-Global 模型。

将调整的新投人值代替原来投人值, 产出不 变,重新投人公式(1)运算。

\subsection{2 标准差椭圆}

标准差椭圆由 Lefever 提出 ${ }^{\left[{ }^{[17]}\right.}$, 现多用于刻画地 理要素在二维空间的分布和移动特征, 主要以中 心、长轴、短轴为基本参数对地理要素进行定量描 述。公式如下:

平均中心: $\overline{X_{w}}=\frac{\sum_{i=1}^{n} w_{i} x_{i}}{\sum_{i=1}^{n} w_{i}} ; \overline{Y_{w}}=\frac{\sum_{i=1}^{n} w_{i} y_{i}}{\sum_{i=1}^{n} w_{i}}$

$\mathrm{x}$ 轴标准差: $\sigma_{x}=\frac{\sqrt{\sum_{i=1}^{n}\left(w_{i} \bar{x}_{i} \cos \theta-w_{i} \overline{y_{i}} \sin \theta\right)}}{\sum_{i=1}^{n} w_{i}^{2}}$

$$
\mathrm{y} \text { 轴标准差: } \sigma_{y}=\frac{\sqrt{\sum_{i=1}^{n}\left(w_{i} \bar{x}_{i} \sin \theta-w_{i} \overline{y_{i}} \cos \theta\right)}}{\sum_{i=1}^{n} w_{i}^{2}}
$$

式中 $\left(x_{i}, y_{i}\right)$ 为研究对象的空间区位; $w_{i}$ 为权重; $i$ 为各 决策单元; $x$ 和 $y$ 分别表示各点距离区域中心的相对 坐标; $\tan \theta$ 可以得到分布格局的转角; $\sigma_{x}$ 和 $\sigma_{y}$ 分别为 沿 $x$ 轴和 $y$ 轴的标准差。以上计算可借助 GIS 10.2 软件实施。

\subsection{3 面板门槛模型}

借鉴Hanse等面板门槛模型 ${ }^{[18]}$, 构建海洋经济 效率影响因素的面板门槛模型, 具体模型如下:

$$
\begin{aligned}
Y_{i t}= & \alpha+\beta_{1} X_{i t} \times I\left(M \leqslant \delta_{1}\right)+\beta_{2} X_{i t} \times I\left(\delta_{1}<M \leqslant \delta_{2}\right) \\
& +\beta_{3} X_{i t} I\left(\delta_{2}<M \geqslant \delta_{3}\right)+\beta_{4} X_{i t} I\left(M \geqslant \delta_{3}\right) \\
& +\gamma_{1} Z_{i t}+\gamma_{2} Z_{i t}+\gamma_{3} Z_{i t}+\mu_{i}+\varepsilon_{i t}
\end{aligned}
$$

式中 $i$ 和 $t$ 分别表示省份和时间; $Y_{i t}$ 为被解释变量, $X_{i t}$ 为核心解释变量, $Z_{i t}$ 为控制变量; $\alpha$ 为截距项; $\beta_{i}$ 为核 心解释变量估计系数; $\gamma_{i}$ 为控制变量估计系数; $M$ 为 门槛变量 $; \delta_{1} 、 \delta_{2} 、 \delta_{3}$ 为待估的三个门槛值; $I($.$) 为示性$ 函数; $\mu_{i}$ 表示不随时间变化的各省截面的个体差异, 即模型为个体固定效应模型; $\varepsilon_{i t}$ 为随机干扰项且服 从独立同分布。

\section{2 指标选取}

第一、第三阶段指标选取。区域海洋经济发展 中, 资源、环境、经济 (Resources, Environment and Economy, REE) 三个子系统构成一个复杂巨系统, 各子系统间存在密切的互动联系,海洋经济发展过 程中不可避免地消耗各种资源并产生和排放环境 污染物 ${ }^{[19]}$ 。同时海洋经济也是一个典型的投人产出 系统, 投人各种海洋资源产出海洋经济效益, 但在 海洋经济生产过程中不仅产出期望产出, 也会产出 非期望产出, 如污染环境的废水、废气 ${ }^{[20]}$ 。本文在传 统经济学的投人产出系统基础上,从资源、环境、经 济三大系统出发构建指标体系, 在第一、三阶段共 选取 8 个指标 (见表 1 )。投人角度即资源方面选取 资源要素、人力要素、资本要素, 期望产出即经济方 面以海洋经济生产总值替代, 非期望产出即环境方 面以废水直排人海量和二氧化硫排放量替代。因 海洋经济三大支柱产业为海洋交通运输、滨海旅 游、渔业养殖, 故资源要素分别以港口码头泊位数、 海洋机动渔船年末拥有量 (渔业方面不仅包括近海 
表 1 海洋经济效率第一、二、三阶段指标选取

Table 1 Index selection for first, second, third stages of marine economic efficiency

\begin{tabular}{|c|c|c|c|}
\hline 目标层 & 准则层 & 指标层(第一、三阶段) & 指标层(第二阶段) \\
\hline 投人 & 资源系统 & $\begin{array}{l}\text { 年末涉海从业总人数/万人、固定资本存量/亿元 } \\
\text { 海洋机动渔船年末拥有量/艘、星级饭店数量/家 } \\
\text { 港口码头泊位数/个 }\end{array}$ & $\begin{array}{l}\text { 海洋科研人力资本 } / \text { 人 } \\
\text { 政府科教支持力度 } / \%\end{array}$ \\
\hline \multirow[t]{2}{*}{ 产出 } & 经济系统 & 海洋 GDP/亿元 & $\begin{array}{l}\text { 陆域经济发展水平/(万元/人)、地区对外开放水平 } / \% \text { 、 } \\
\text { 海洋经济发展水平/(万元/人)、海洋产业结构水平 } / \%\end{array}$ \\
\hline & 环境系统 & 废水直排人海量/万 $\mathrm{t} 、 \mathrm{SO}_{2}$ 排放量 $/ \mathrm{t}$ & 单位海洋 GDP 能耗/(万元/t) \\
\hline
\end{tabular}

养殖, 也包括远洋捕捞, 渔业养殖面积指标并不具 有全面代表性,海洋机动渔船年末拥有量不仅涵盖 近海捕捞, 也包括远洋捕捞, 对渔业资源更具代表 性)、星级饭店数量(近年来滨海旅游以散客为主, 以城市本身对游客吸引力作为旅游方面投人) 替 代, 将三者标准化加权求和作为资源总投人。人力 要素以年末涉海从业总人数替代。受现实统计数 据影响, 无法获取海洋经济固定资产投资, 故以各 地区总的固定资产投资替代, 因经济投资对海洋经 济发展的影响不仅限于当期,还基于往年所形成的 资本存量, 故以永续盘存法对沿海 11 个省市的固定 资本存量进行估算,计算公式为:

$$
K_{i t}=K_{i t-1}(1-\delta)+I_{i t} / P_{t}
$$

式中 $\delta$ 为折旧率 $(9.6 \%)^{[2]} ; K_{i i}$ 为 $i$ 地区第 $t$ 年的固定资 本存量; $I_{i t}$ 为 $i$ 地区第 $t$ 年的固定资产投资; $P_{t}$ 为以 2000 年为基期的固定资产投资价格指数; 基年固定 资本存量采用 Yong ${ }^{[2]}$ 的方法, 以基年固定资产投资 除以 $10 \%$ 。为使各地区海洋经济总产值更具可比 性, 期望产出用 2000 年为基期的 GDP 平减指数对 其进行平减; 非期望产出标准化加权求和, 形成总 的非期望产出。

第二阶段指标选取。在资源、环境、经济巨系 统基础上共选取 7 个指标 (见表 1)。资源方面, 选取 海洋科研人力资本 (海洋科研机构人员数)、政府对 海洋科技支持力度 (政府科技三项支出占财政总支 出比重) 2 个指标。经济方面, 陆域方面选取地区对 外开放水平（进出口贸易总额占 GDP 比重）、陆域经 济发展水平( 陆地人均 GDP), 海洋经济方面选取海 洋经济发展水平 (海洋人均 GDP)、海洋产业结构水 平 (海洋第三产业占海洋 GDP 比重) 共 4 个指标。 环境方面, 选取单位海洋 GDP 能耗 (陆域单位 GDP 能耗乘以海洋 GDP 占陆域 GDP 比重) 1 个指标。为
避免出现解释变量共线及解释变量与被解释变量 相关性过小问题, 利用 Eviews8.0 做回归分析, 最终 篮选出对各投人冗余量造成显著影响的 4 个指标: 海洋科研人力资本、陆域经济发展水平、海洋经济 发展水平、单位海洋 GDP 能耗。

海洋经济效率第一、三阶段投人产出指标及第 二阶段外在环境因素选取具体见表 1 。

海洋经济效率影响因素指标选取。本文以海 洋经济效率 $(Y)$ 为被解释变量; 以海洋经济发展区 位熵 $(X 1, \%)$ 、海洋产业结构 $(X 2, \%)$ 、海洋科研人力 资本 $(X 3, \%)$ 、海洋环保技术水平 $(X 4$,万元 $/ \mathrm{t})$ 、海洋 经济政策影响 ( $X 5$, 亿元) 为解释变量; 陆域经济发 展水平 $(Z 1$,万元/人)、对外开放水平 $(Z 2, \%)$ 、政府 对海洋科技支持力度 ( $Z 3$, 亿元) 为门槛变量 (为防止 数据不平稳, 对其取对数), 构建面板门槛模型。 $X 1$ 为该省市海洋 GDP 在沿海 11 省市总体海洋 GDP 中 所占的比重与该省市陆域 GDP 在沿海 11 省市总体 陆域 GDP 中的比重的比值; $X 2$ 为海洋第三产业占海 洋 GDP 比重; $X 3$ 为海洋科研人数与涉海从业总人数 比值; $X 4$ 为单位海洋 GDP 能耗; $X 5$ 为该省市对海洋 经济投资总额; $Z 1$ 为陆域人均 GDP; $Z 2$ 为进出口贸易 总额与陆域 GDP 比值 $; Z 3$ 为政府对海洋科技投资。

\section{3 数据来源}

数据主要源于 2000-2015年《中国海洋统计年

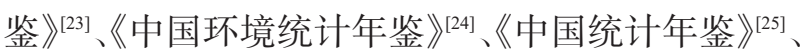

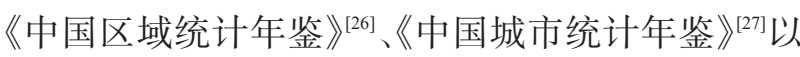
及各省市统计年鉴, 部分缺失数据, 根据实际情况 用多重插补法进行平滑处理。

\section{3 三阶段 DEA 结果分析}

\section{1 第一阶段超效率 SBM-Global 实证结果分析}

根据公式(1)运用全局参比法计算出中国沿海 
地区 2000-2015年海洋经济效率, 发现效率值不超 过 1 时, 传统 SBM-Global 计算所得结果与超效率 SBM-Global 相同。然而当决策单元有效时, 超效率 模型明显可对有效决策单元进一步排序分析。因 此, 将第一、三阶段传统 SBM-Global模型改进为超 效率SBM-Global模型是合理且必要的。

MaxDEA 软件计算结果显示 (表 2), 在不考虑 环境因素和随机误差影响时, 全国海洋经济效率平 均值为 0.543 , 属于无效率, 超过全国平均值的地区 占 $45 \%$, 且地区间差异较大。其中山东、广东等属 于海洋强省, 在全国排名中却比较靠后, 可能是受 到外部环境因素和随机误差的影响。时间序列上 呈先上升后下降最终趋于平稳的趋势(图 1), 在 2003 年出现峰值, 除 2003 年峰值效率属低效率外, 其它 年份均为无效,距离效率高效仍有很大进步空间。

\section{2 第二阶段相似 SFA 结果分析}

以各决策单元三个投人的圥余量为因变量, 海 洋科研人力资本、陆域经济发展水平、海洋经发展 水平、单位海洋 GDP 能耗为自变量, 构建相似 SFA 模型, 利用Front 4.1 软件投人运算。分析结果显示 (表 3), $\gamma$ 值都接近于 1 , 且都通过了 $1 \%$ 水平下的显

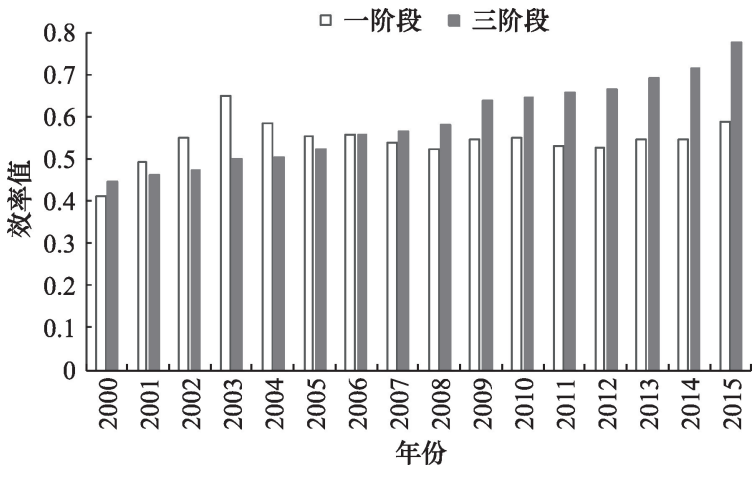

图 12000 -2015 年全国海洋经济效率平均值

Figure 1 Average value of national marine economic efficiency from 2000 to 2015

著性检验,即各决策单元外部技术效率存在较大差 异, 随机误差影响很小。说明第二阶段使用 SFA 模 型对环境变量进行剥离具有合理性。

\section{3 第三阶段调整后的超效率 SBM-Global 结果 分析}

将调整后的各投人变量重新投人 MaxDEA 计 算(表 2)。与一阶段相比,各省市平均效率值都出 现了不同程度变化, 海南、福建、天津效率值下降, 说明这 3 个地区一阶段受到好的外部环境和运气影

表 2 中国沿海地区海洋经济效率第一、三阶段结果对比

Table 2 Comparison of first, third stages of marine economic efficiency in China's coastal areas

\begin{tabular}{|c|c|c|c|c|c|c|c|c|c|c|c|c|}
\hline 省份 & 天津 & 河北 & 辽宁 & 上海 & 江苏 & 浙江 & 福建 & 山东 & 广东 & 广西 & 海南 & 全国 \\
\hline 一阶段 & 0.874 & 0.422 & 0.428 & 0.776 & 0.352 & 0.424 & 0.620 & 0.500 & 0.581 & 0.263 & 0.734 & 0.543 \\
\hline 三阶段 & 0.799 & 0.438 & 0.511 & 0.885 & 0.464 & 0.537 & 0.549 & 0.688 & 0.736 & 0.282 & 0.567 & 0.587 \\
\hline 一阶段排名 & 1 & 9 & 7 & 2 & 10 & 8 & 4 & 6 & 5 & 11 & 3 & \\
\hline 三阶段排名 & 2 & 10 & 8 & 1 & 9 & 7 & 6 & 4 & 3 & 11 & 5 & \\
\hline
\end{tabular}

表 3 第二阶段相似 SFA 结果分析

Table 3 Analysis of second stage similar SFA results

\begin{tabular}{|c|c|c|c|c|c|c|}
\hline & \multicolumn{2}{|c|}{ 涉海从业总人数 } & \multicolumn{2}{|c|}{ 固定资本存量 } & \multicolumn{2}{|c|}{ 资源投人 } \\
\hline & 系数 & $\mathrm{T}$ 值 & 系数 & $\mathrm{T}$ 值 & 系数 & T值 \\
\hline 常数项 & 56.00 & $2.40 * *$ & 2.00 & $2.10 * * *$ & -430.00 & $-5.60 * * *$ \\
\hline 海洋科研人力资本 & 110.00 & 1.50 & -0.55 & $-1.90^{*}$ & $-0.30 \mathrm{E}+04$ & $-10.00^{* * *}$ \\
\hline 海洋经济发展水平 & -30.00 & $-3.40 * * *$ & 0.09 & $2.20 * *$ & $2.50 \mathrm{E}+04$ & $21.00 * * *$ \\
\hline 陆域经济发展水平 & 120.00 & $4.80 * * *$ & -0.32 & $-2.90 * * *$ & $-6.00 \mathrm{E}+04$ & $-20.00^{* * *}$ \\
\hline 单位海洋 GDP 能耗 & $-0.70 \mathrm{E}-04$ & -0.87 & $-0.63 \mathrm{E}-04$ & $-2.10 * *$ & 6.90 & $4.60 * * *$ \\
\hline sigma-squared & $4.00 \mathrm{E}+04$ & $600.00 * * *$ & 0.98 & $5.20 * * *$ & $3.30 \mathrm{E}+08$ & $3.30 \mathrm{E}+08 * * *$ \\
\hline$\gamma$ & 0.92 & $100.00 * * *$ & 0.95 & $100.00 * * *$ & 0.52 & $9.80 * * *$ \\
\hline log likelihood & -990.00 & & -39.00 & & $-0.20 \mathrm{E}+04$ & \\
\hline
\end{tabular}

注: ***和***分别表示在 $10 \%, 5 \%$ 和 $1 \%$ 水平上显著。 
响出现效率高估现象, 其余省市相对效率值均上 升, 表明这些省市在三阶段剔除外在环境因素和随 机误差影响后,其内部真正的管理技术效率上升, 与一阶段疑问相对应。

调整后的名次除广西稳居倒数第一外, 其它各地 区均有不同程度变动, 其中山东上升 2 名, 福建和海 南下降 2 名,天津、河北、辽宁下降 1 名, 江苏、浙江、 上海上升 1 名, 排名更加符合实际。全国效率均值来 看 (图 1), 三阶段内部管理效率整体稳步上升,一阶 段效率先上升再下降, 最后趋于平稳, 且存在整体 低估现象。以上分析表明, 使用三阶段超效率 SBM-Global研究中国海洋经济效率很有必要。

\section{4 海洋经济效率时空演化特征}

\section{1 时间演化特征}

2000-2015 年全国海洋经济效率平均值中 (图 1),2000-2008 年海洋经济效率无效,2008 年以 后变为低效,并逐渐升高到 0.78 , 整体呈稳步上升态 势, 有望升高到中等有效。在中国海洋经济效率增 长率方面, 整体上呈波动上升趋势, 2000-2005年 “十五规划” 期间波动上升, 平均增长率为 $1.5 \%$; 2006-2010 年“十一五规划”期间除2008 年(1.5\%) 和 2009 年 $(5.5 \%)$ 比较突出外, 其余较为平稳, 平均 增长率为 $2.5 \% ; 2011-2015$ 年 “十二五规划” 时期后 三年基本呈直线上升趋势, 由 2013 年的 $2.7 \%$ 增加 到 2015 年的 $6.2 \%$, 平均增长率为 $2.6 \%$ 。效率类型 也从侧面佐证了此趋势, 有效省市占比从 2000 年的 $9 \%$ 上升到 2015 年的 $64 \%$, 有效省市从上海的一枝 独秀演变为上海、天津等 7省的遍地开花;2007年以 后效率中等省市开始出现, 2015 年中等以上效率的 省市占比高达 $36 \% ; 2012$ 年以后上海、天津 2 省市独 占鳌首,效率达到高效并不断上升。

分析其原因,2000-2005 年“十五规划”时期， 国家提出海洋经济处于成长期, 要大力发展海洋经 济保持其高速增长, 把发展海洋经济作为振兴国民 经济的重大举措, 但同时也存在只重规模不求质量 的粗放发展模式, 造成资源浪费和环境污染; 2006-2010年“十一五规划”初期国家确立加快建 设“资源节约型环境友好型社会”总体思路,各地区 开始调结构转方式, 但边际效应未显现, 特别是
2007 年和 2008 年海洋经济效率较上年增长率仅为 $0.9 \%$ 和 $1.5 \%, 2009$ 年环保投人边际效应显现后效率 增长率上升到 $5.5 \% ; 2011-2015$ 年“十二五规划”时 期延续上一个五年规划趋势, 增长较平稳, 同时深 人践行科学发展观,继续加快建设资源节约型环境 友好型社会, 坚持海陆统筹,开创科学发展新局面, 海洋经济由速度规模型向质量效益型转变。

为体现各地区时序上的差异,计算得到海洋经 济效率绝对差异和相对差异 (图 2)。其中表征绝对 差异的标准差与表征相对差异的变异系数走势基 本一致,呈稳步上升趋势, 相对差异趋势稍缓, 2000-2005 年二者增长趋势较缓, 平均增长率分别 为 $3.9 \%$ 和 $2.2 \% ; 2006-2010$ 年增长加快, 2009 年都 出现阶段内峰值,平均增长率分别达 $7.3 \%$ 和 $3.8 \%$; 2011-2015 年增长速度最快, 2015 年均出现研究阶 段内最高值,平均增长率分别高达 $11.2 \%$ 和 $6.2 \%$ 。 总体上,中国沿海地区海洋经济效率区域间绝对差 异和相对差异稳步上升。

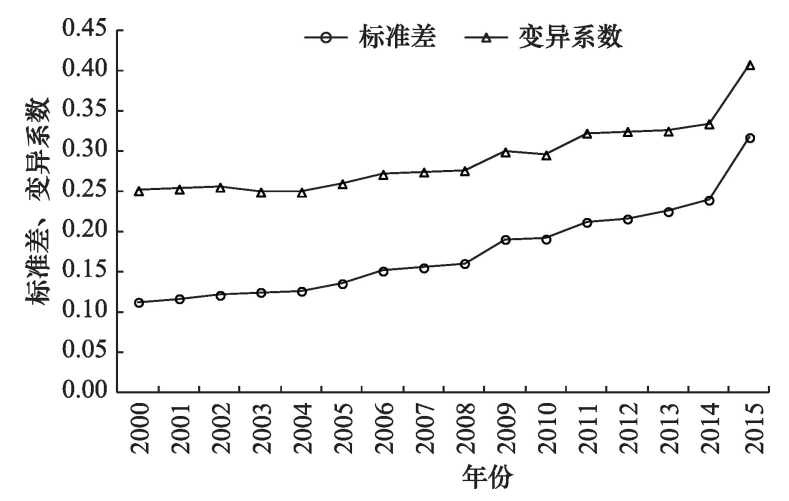

图 $22000-2015$ 年中国海洋经济效率绝对差异和相对差异

Figure 2 Absolute differences and relative differences of marine economic efficiency in China from 2000 to 2015

分析其原因, 2000-2005 年市场经济制度确立 后的第一个五年计划“十五规划”时期,偏重经济增 长速度, 各地区大力开发海洋资源, 扩大海洋经济 规模,海洋经济发展处于起步阶段,此时天津、上海 等省市科技、产业结构等优势都还未发挥相对作 用,各地区海洋经济效率相对都较低,海洋经济效 率区域间绝对差异和相对差异都较小且增长缓 慢。2006-2010年“十一五规划”期间构建资源节 约型和环境友好型社会, 开始改变之前产业结构单 一,开发方式粗放的发展模式,也开始注重对环境 和生态保护投资,初期经济基础好的省市如上海、 
天津、广东等环境边际效应并未显现, 2009年边际 效应显现, 效率迅速上升, 效率的地区间绝对和相 对差异变大。2011-2015 年 “十二五规划”时期, 国 家强调深人贯彻落实科学发展观, 坚持陆海统筹, 着力推进海洋产业结构调整升级, 增强科技创新能 力, 强化海洋资源集约利用和生态环境保护, 保有 领先优势省市的产业结构逐渐合理, 更多发展科技 含量高、环境污染少的新兴产业, 相对落后省市则 更容易承接资源消耗高、环境污染大的海洋产业， 海洋经济效率的地区绝对和相对差异迅速上升。

\section{2 空间演化特征}

4.2.1 中国沿海地区海洋经济效率空间动态分布 2000-2015 年海洋经济效率空间动态演变特 征明显, 总体上呈东北-西南移动趋势, 最终向东北 方向移动 (图 3a)。椭圆面积先增加后下降, 海洋经 济效率分布先扩大后缩小。以下主要从椭圆的重 心、方向和范围方面对中国海洋经济效率空间动态 变化进行刻画。

2000-2015 年海洋经济效率重心移动轨迹中 (图3b), 以 2005 年、2008 年、2010 年为转折点分为 四个阶段。在重心转移方向上, 2000-2005 年、

a. 椭圆分布

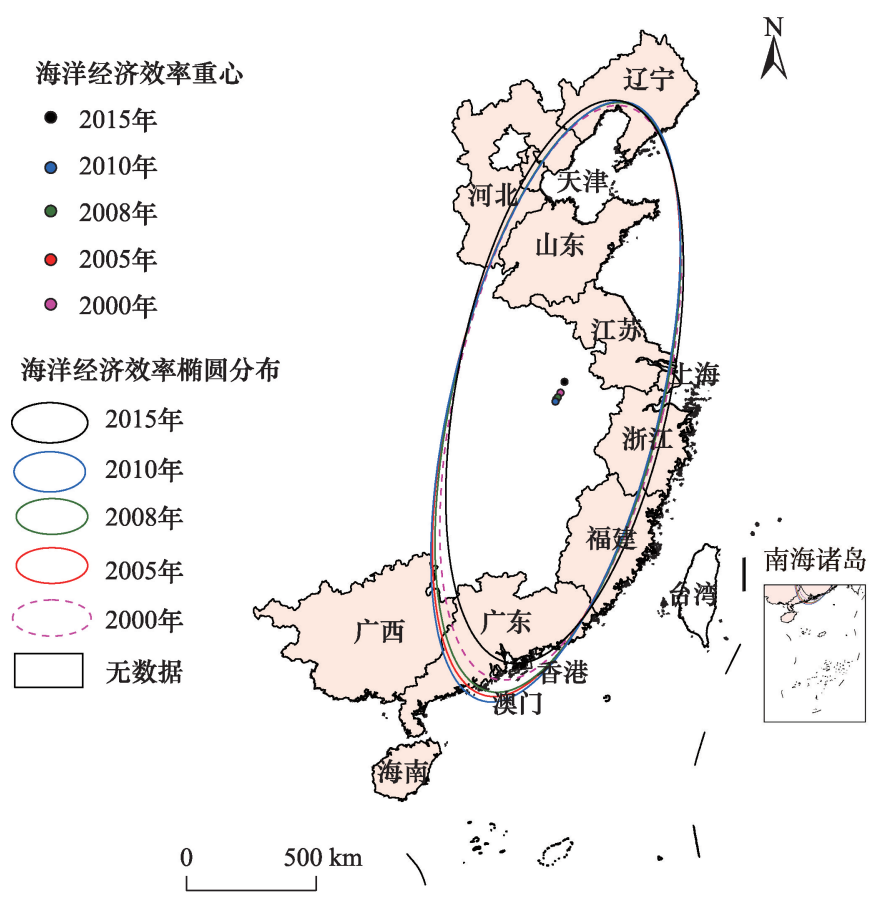

2008-2010 年明显向西南偏移, 2005-2008 年、 2010-2015 年明显向东北偏移。移动距离上, 向北 总距离超过向南总距离, 向东总距离超过向西总距 离, 南北移动距离大于东西移动距离, 其中南北 移动总距离是东西移动总距离的 10.6 倍; 总位移 $29.14 \mathrm{~km}$, 其中向东移动 $16.4 \mathrm{~km}$, 向北移动 $141.7 \mathrm{~km}$ (图 4a)。效率重心总体上呈东北-西南分布, 2000-2005 年由东部海洋经济圈向南部海洋经济 圈方向转移;2005-2008 年向东部海洋经济圈方向 转移; 2008 - 2010 年再次向南部海洋经济圈方向转 移;2010-2015 年则转向北部海洋经济圈。

从标准差椭圆分布形状来看 (图 $4 b$ ), 长轴标准 差始终大于短轴标准差, 呈明显的东北-西南方向 分布格局; 长短半轴标准差整体上先减小后增大, 2000 - 2010 年长半轴和短半轴标准差逐渐减小, 椭 圆面积逐渐减小, 海洋经济效率在南北和东西方向 上都呈收缩趋势; 2010-2015 年长半轴和短半轴标 准差都逐渐增大, 椭圆面积不断增大, 海洋经济效 率在东西和南北方向上均呈分散趋势, 北、东、南海 洋经济圈势均力敌,呈三足鼎立之势, 与中国现阶 段的环渤海、长三角、珠三角为中心的三大经济圈

b. 重心转移轨迹

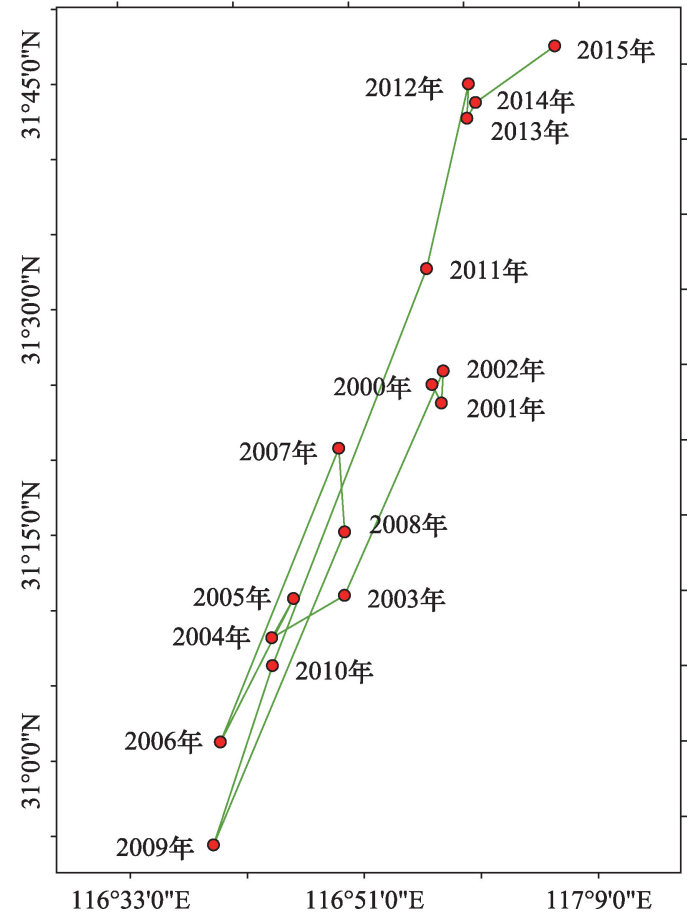

图 $32000-2015$ 年中国沿海地区海洋经济效率重心偏移

Figure 3 The center of gravity migration of marine economic efficiency in China's coastal areas from 2000 to 2015 
2018年 10 月
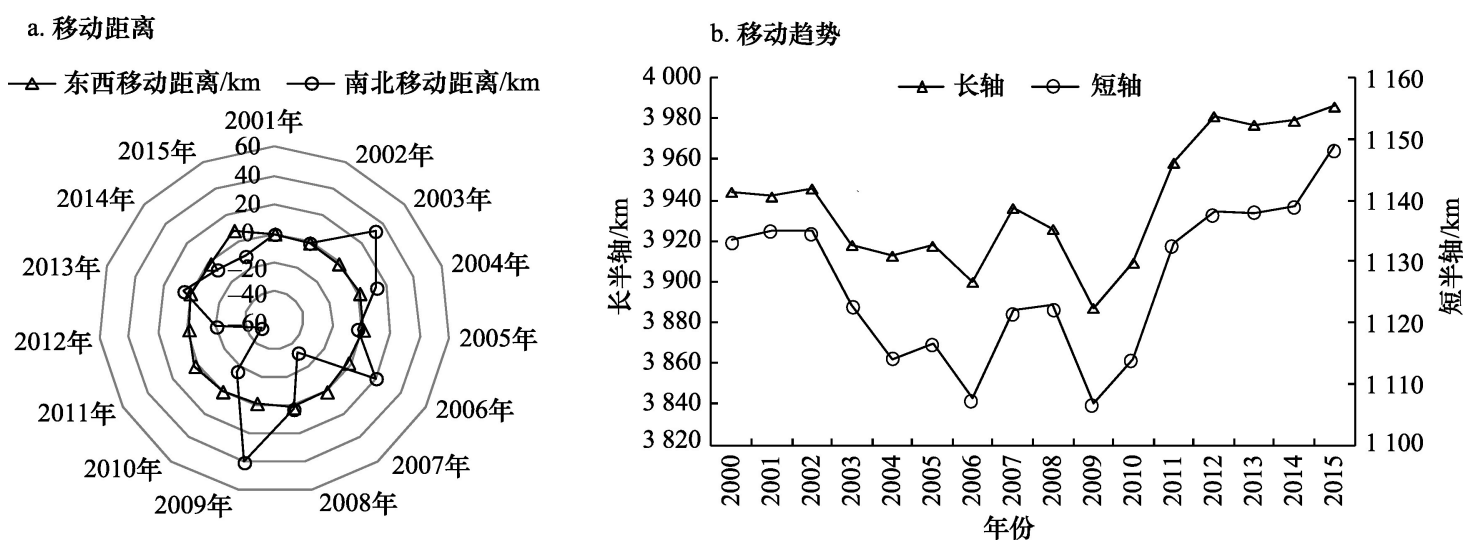

图 $42001-2015$ 年中国沿海地区海洋经济效率重心移动距离及标准差椭圆长短轴变化

Figure 4 The shift of the center of gravity of marine economic efficiency in China's coastal areas and the variation of the standard deviation ellipse length and short axis from 2001 to 2015

发展现状相吻合。

重心转移主要原因为, 2000-2005 年市场经济 确立后的第一个五年计划“十五规划”,以大力发展 市场经济促进经济增长为主要目的, 此时先天资源 条件占优势的南部沿海地区, 特别是海南海洋经济 效率迅速上升,所以效率重心由东部海洋经济圈向 西南方转移。2005-2008 年“十一五规划”提出以 发展新兴技术和提高服务业为主,建设资源节约型 和环境友好型社会, 此时经济基础雄厚的环渤海沿 海地区和长三角沿海地区在科技和环境生态方面 边际效益开始显现, 经济效率明显提升, 重心北 移。2008-2010年效率重心向东部沿海经济圈转 移,上海是重要的国际经济、金融、航运、贸易中心， 多年来一直保持世界第一大港的地位; 江苏发挥中 国重要的交通枢纽功能,并打造沿海新型工业基 地; 浙江为中国大宗国际物流中心, 在生态和环境 保护方面也因强大的经济实力做后盾取得良好效 果, 东部沿海经济圈海洋经济效率领先三大经济 圈。2010-2015 年国家经济进人新常态, 国家相继 提出发展海洋强国、“一带一路”等发展海洋经济的 政策, 京津冀一体化逐步开展, 山东蓝色海洋经济 区建设逐渐步上正轨, 上海自贸实验区成立, 效率 重心逐渐向北偏东转移。

4.2.2 三个海洋经济圈内部海洋经济效率空间动态 分布

中国沿海地区海洋经济效率地区差异明显, 整 体上呈现北、中、南三级格局分布, 为更细致展现各
区域内部海洋经济效率空间动态演变, 根据国家海 洋经济规划总体布局, 分别对北部、东部、南部三个 海洋经济圈进行研究(如图 5)。

北部海洋经济圈标准差椭圆呈东北-西南方向 分布, 长轴和短轴标准差都呈减小趋势, 椭圆面积 不断缩小, 圈内海洋经济效率分布不断极化。重心 转移大致呈 L 状, 主要分为 2000-2010 年、20102014年、2014-2015 年三个阶段。2000-2010年效 率重心向西偏北转移, 天津作为最早的沿海开放城 市, 有着雄厚的经济基础, 再加上 2005 年天津滨海 新区成立, 成为带动天津海洋经济发展的新引擎; 2003 年中共中央、国务院发布《关于实施东北地区 等老工业基地振兴战略的若干意见 $\rangle^{[28]}$, 辽宁海洋经 济效率在此基础上实现快速增长。2010-2014 年 海洋经济效率重心向西偏南转移, 天津在京津冀一 体化过程中,科研投人和利用率不断提高; 山东凭 借自身强大科研实力, 以及国家提出打造“山东半 岛蓝色经济区”的国家策略,海洋经济效率提升速 度加快。2014-2015 年“十二五规划”末期重心大 幅度向西北方向转移, 天津海洋生物医药、海洋装 备制造等海洋新兴产业迅速发展,传统产业不断改 造升级，《天津市科技兴海行动》 ${ }^{[29]}$ 政策边际效应显 现; 辽宁沿海带作为东北地区唯一出海口, 在两次 东北振兴格局中发挥重要区位优势, 海洋经济效率 由无效达到弱有效。

东部海洋经济圈标准差椭圆呈西北-东南方向 分布,长轴标准差波浪式上升,短轴标准差波浪式 
a. 三大海洋经济圈海洋经济效率椭圆分布

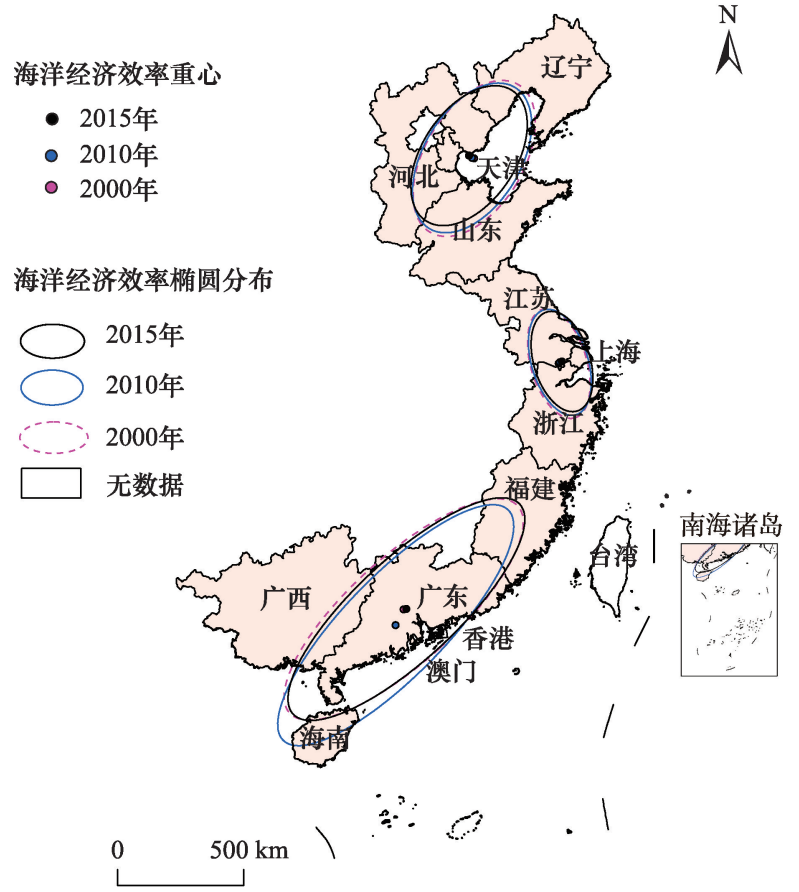

b. 三大海洋经济圈海洋经济效率重心转移轨迹

北部海洋经济圈

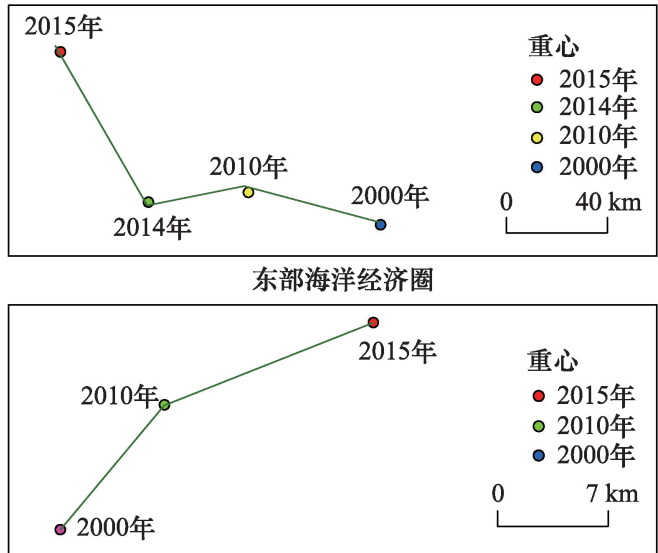

南部海洋经济圈

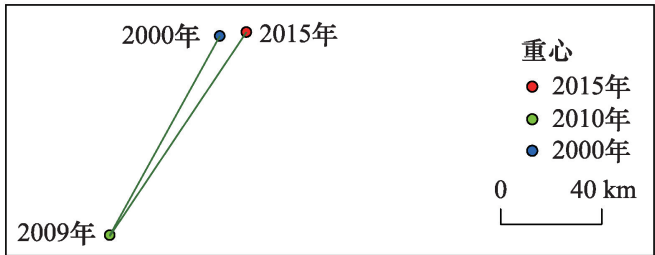

图 $52000-2015$ 年三大海洋经济圈内部标准差椭圆及重心转移

Figure 5 The standard deviation ellipse and gravity center transfer in the three economic circles from 2000 to 2015

下降,椭圆面积总体不断下降,海洋经济效率地区 差异不断增大。重心移动轨迹主要分为 20002010 年、2010-2015 年两个阶段。2000-2010年效 率重心由西南向东北 (上海)方向转移, 上海作为首 批对外开放城市, 经济基础雄厚, 北接江苏南临浙 江, 区位优势明显, 其海洋交通和海洋船舶业在全 国保有领先地位, 海洋生物医药、海洋装备制造业 等新兴产业快速发展, 形成海洋三产为主, 一产占 比不到 $1 \%$ 的特色产业结构; 海洋环保方面实施两 轮“环保三年行动计划”, 海洋生态状况得到有效监 控。2010-2015年效率重心继续向东北方向偏移， 但东偏幅度较大, 上海海洋经济效率继续领先; “十 二五规划”初期国务院批复首个国家级海洋经济示 范区规划《浙江海洋经济发展示范区规划》 ${ }^{[30]}$, 将浙 江省海洋经济发展纳人国家策略, 再加上浙江省本 身较早推行资源市场化配置, 市场机制规范、灵活, 在海洋经济优化配置、促进海洋经济可持续发展方 面取得了卓越成果。

南部海洋经济圈标准差椭圆呈东北-西南方向 分布, 长轴标准差先上升后下降, 短轴标准差波浪 式下降, 栯圆面积不断减小, 区域内海洋经济效率
分布集中, 海洋经济效率地区差异显著。根据重心 转移规律, 分为 2000-2009 年和 2009-2015 年两 个阶段。2000-2009年海洋经济效率重心向西南 方向 (海南)转移, 主要原因是海南油气矿产等海洋 资源丰富, 以海洋油气利用为主的海洋新兴产业迅 速发展, 滨海和海岛旅游业发达, 海洋三产比重高 达 $50 \%$ 以上,整体环境水平优越,海洋经济效率 高。2009-2015 年效率重心向东北方向 (广东、福 建)转移, 广东、福建两省海洋经济起步早, 依托珠 三角区位优势,并不断推进海洋产业结构调整升 级,发展战略性新兴产业和高新技术产业,增强科 技创新能力, 强化海洋资源集约利用和生态环境保 护,在海洋经济效率方面优势显著。

\section{5 海洋经济效率影响因素分析}

采用面板门槛模型, 分析海洋经济效率影响因 素,其优点在于,可分析计算解释变量对被解释变 量的边际影响是否存在拐点, 以及在拐点前后会发 生怎样的变化。在进行面板门槛回归估计之前, 首 先对面板数据进行门槛存在性和门槛数量检验, 借 鉴吴伟平和刘乃全做法, 分别设置单一门槛、双重 
门槛和三重门槛, 根据公式(7)利用Bootstrap 法计算 得到 $F$ 统计值、 $p$ 值、门槛临界值, 检验结果见表 4 。

表 5 显示, 以陆域经济发展水平为门槛变量, 海 洋经济区位熵为核心解释变量, 以 0.9 为临界值存 在单门槛效应; 以海洋产业结构为门槛变量和核心 解释变量, 不存在门槛效应; 以海洋科研人力资本
为门槛变量和核心解释变量,在 $10 \%$ 的水平上存在 单一门槛; 以海洋环保技术水平为门槛变量和核心 解释变量,则存在以 0.46 为临界值的单门槛。

当陆域经济发展水平小于 0.9 万元/人时,海洋 经济区位熵对海洋经济效率起负向作用,虽然海陆 经济联系紧密,但是海洋经济起步晚,最初只是作

表4 中国沿海地区海洋经济效率影响因素门槛估计结果

Table 4 Threshold estimates of factors affecting marine economic efficiency in China's coastal areas

\begin{tabular}{|c|c|c|c|c|c|c|c|}
\hline 门槛变量 & 门槛数 & $\mathrm{F}$ 值 & $1 \%$ & $5 \%$ & $10 \%$ & 门槛值 & 置信区间 \\
\hline \multirow[t]{3}{*}{ 海洋经济区位熵 $X 1$} & 单一 & $40.05 * *$ & 65.29 & 31.91 & 20.67 & 0.90 & {$[0.82,0.93]$} \\
\hline & 双重 & 5.15 & 35.78 & 16.57 & 11.56 & 6.31 & {$[4.92,6.71]$} \\
\hline & 三重 & $6.52 *$ & 11.71 & 7.07 & 5.07 & 4.95 & {$[0.73,7.93]$} \\
\hline \multirow[t]{2}{*}{ 海洋产业结构 $X 2$} & 单一 & 22.41 & 54.00 & 34.40 & 27.04 & 0.61 & {$[0.26,0.65]$} \\
\hline & 双重 & 4.22 & 17.13 & 10.99 & 8.72 & 0.65 & {$[0.61,0.68]$} \\
\hline \multirow[t]{3}{*}{ 海洋科研人力资本 $X 3$} & 单一 & $7.23^{*}$ & 21.15 & 11.03 & 7.27 & 1.42 & {$[0.00,2.70]$} \\
\hline & 双重 & 2.94 & 17.90 & 11.76 & 6.27 & 8.43 & {$[0.03,10.16]$} \\
\hline & 三重 & $12.01 * * *$ & 14.17 & 9.20 & 7.39 & 2.42 & {$[0.03,2.70]$} \\
\hline \multirow[t]{2}{*}{ 单位海洋 GDP能耗 $X 4$} & 单一 & $12.63^{*}$ & 25.39 & 17.20 & 12.66 & 0.46 & {$[0.05,0.58]$} \\
\hline & 双重 & 11.46 & 23.04 & 15.46 & 12.02 & 0.56 & {$[0.05,0.78]$} \\
\hline \multirow[t]{3}{*}{ 海洋经济政策 X5 } & 单一 & 6.82 & 20.94 & 11.74 & 7.55 & 196.15 & {$[34.66,801.78]$} \\
\hline & 双重 & $15.87^{*}$ & 34.95 & 20.98 & 9.92 & 1178.78 & {$\left[\begin{array}{lllll}1 & 128.39,1 & 188.60\end{array}\right]$} \\
\hline & 三重 & 1.71 & 13.81 & 8.07 & 6.22 & 540.85 & {$[34.66,619.47]$} \\
\hline
\end{tabular}

注: ***、***分别表示在 $10 \% 、 5 \% 、 1 \%$ 的水平上显著。

表 5 中国沿海地区海洋经济效率影响因素门槛参数回归结果

Table 5 Threshold parameter regression results for factors affecting marine economic efficiency in China's coastal areas

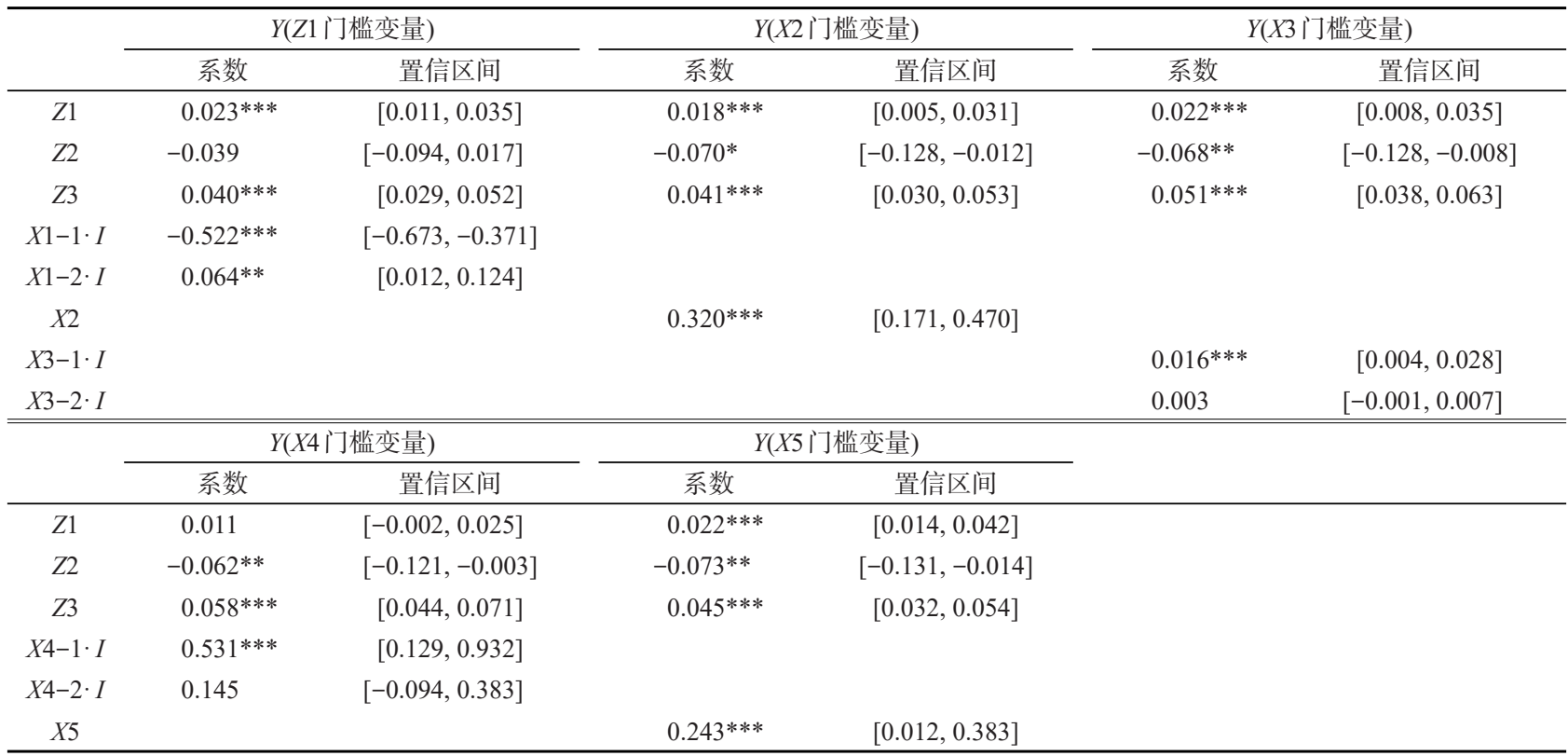

注: $X 1 、 X 2 、 X 3 、 X 4$ 是与门监变量 $Z 1 、 X 2 、 X 3 、 X 4$ 对应的核心解释变量, 门槛变量对应取值范围: $X 1-1 \cdot I(X 1 \Im 0.90) 、 X 1-2 \cdot I(X 1 \geqslant 0.90) 、 X 3-1 \cdot I$ $(X 3 \leqslant 1.42) 、 X 3-2 \cdot I(X 3 \geqslant 1.42) 、 X 4-1 \cdot I(X 4 \lessgtr 0.46) 、 X 4-2 \cdot I(X 4 \geqslant 0.46)$ 
为陆域经济发展空间、能源不足及污染严重的补充 和延伸, 海洋经济对陆域经济有一定的依赖性, 在 陆域经济发展水平没有达到一定程度时, 对海洋经 济更多的是索取; 当陆域经济发展水平大于 0.9 万 元/人时, 陆域经济发展更加成熟, 有更多人力、物 力、财力扶持海洋经济发展, 陆域经济开始反哺海 洋经济, 海洋经济区位熵对海洋经济效率提高起到 显著正向促进作用。

海洋科研人力资本以每 1000 个海洋从业人员 中有 1.42 个海洋科研人员为临界点存在单一门 槛。当小于临界值时, 海洋科研人力资本对海洋经 济效率影响系数显著为正, 此时海洋科研人力资本 吸收外来科技并进行科技创新, 对于还处于粗放发 展阶段的海洋经济起到促进作用; 而当大于临界值 时, 海洋科研人力资本对海洋经济效率提高作用不 显著, 主要原因是中国海洋经济还处于产业结构转 型过程中, 多数地区还是以劳动密集型海洋产业为 主, 对高新技术产业需求量有限, 另外国内海洋科 技成果中, 内生技术创新不足, 多来自于对外来技 术模仿, 其真正科技发展水平和产品转化率不高。

海洋环保技术水平即单位海洋 GDP 能耗与海 洋经济效率存在非线性关系, 以 0.46 万元/ $\mathrm{t}$ 为临界 点存在单门槛。单位海洋 GDP 能耗小于 0.46 万元/ $\mathrm{t}$ 时, 海洋环保技术水平显著促进海洋经济效率提 高, 即海洋 GDP 能耗倒数每提高 1 个单位, 海洋经 济效率提高 0.531 。当单位海洋 GDP 能耗大于 0.46 万元/ $\mathrm{t}$ 时, 海洋环保技术水平对海洋经济效率提高 的促进作用不明显。因此, 在发展海洋经济时, 应 奋力提高海洋环保技术水平, 提高资源利用率。

海洋产业结构对海洋经济效率影响有显著正 影响, 不存在门槛效应。海洋第三产业比重提高在 海洋经济效率提高中起显著作用, 但中国大部分沿 海地区海洋三产占比并不高, 在改善产业结构和提 高三产内部经济效率方面任重而道远。政府对海 洋科技支持力度虽然能促进海洋经济效率提升, 但 影响度较小,未来应提高政府对海洋科技支持力度, 并注重引导海洋科技成果向海洋产业及产品转化。

陆域经济发展水平对海洋经济效率影响呈显 著正相关。海洋经济是陆域经济发展的延伸, 海洋 经济为陆域经济提供空间和资源, 作为海洋经济腹
地的陆域经济为海洋经济发展提供人力、物力、财力 支持, 因此陆域经济发展对海洋经济发展有显著正 影响, 今后海洋经济发展应更注重海陆协同发展。

地区对外开放水平对海洋经济效率呈显著负 相关。地区对外开放水平提高虽然能够促进海洋 经济发展,但同时可能存在发达国家为改善环境状 况, 将高污染和高消耗海洋产业向发展中国家转移 现象, 同时中国出口商品中初级产品和资源性商品 比重高, 在国际剪刀差状况下对提高海洋经济效率 效果不明显。

海洋经济政策增加力度对海洋经济效率提高 具有显著正向作用。海洋经济政策力度每增加 1 个 单位,海洋经济效率提高 0.24 个单位,在上文分析 中也不难发现, 国家以及地区的海洋经济政策对海 洋经济效率的时空动态演变起到至关重要作用,在 以市场经济这只看得见的手发挥基础调控功能的 基础上,必须发挥政府宏观调控这只看得见的手的 作用, 同时也应该注意把握度,避免造成政策性浪 费,政府扶持与自主发展相结合。

\section{6 结论与建议}

\section{1 结论}

分析结果显示:

（1）一阶段中,超效率 SBM-Global 模型明显优 于传统模型,将第一、三阶段 SBM-Global 模型改进 为超效率 SBM-Global 模型是合理且必要的。全国 效率呈先上升后下降并逐渐趋于平稳的趋势, 进步 空间大,其中山东、广东等省市可能受外在环境因 素影响, 排名与实际不符; 二阶段中, 外在环境变量 对投人圥余影响显著,各决策单元外部技术效率存 在较大差异,随机误差影响很小;三阶段中,全国整 体效率稳步上升,除广西外,各省市排名有不同程 度变动, 山东、广西等省市排名更加符合实际, 与一 阶段疑问相对应，事实证明使用三阶段超效率DEA 研究中国海洋经济效率很有必要。

(2)时间序列上,海洋经济效率增长率整体波 动上升,有效省市全国占比从 2000 年的 $9 \%$ 上升到 2015 年的 $64 \%$, 有效省市从上海的一枝独秀演变为 到上海、天津等 7省市的遍地开花;海洋经济效率区 域绝对差异和相对差异稳步上升; 空间上,全国标 准差邦圆呈东北-西南分布,海洋经济效率分布先 
扩大后紧缩, 重心总体上呈东北-西南移动趋势, 最 终向东北方向移动。北、南部海洋经济圈标准差椭 圆呈西南-东北走向, 东部呈西北-东南走向, 三大 海洋经济圈粗圆面积总体不断下降, 内部地区差异 不断增大。

(3)海洋经济区位熵、海洋科研人力资本、海洋 环保技术水平与海洋经济效率之间存在非线性关 系。海洋经济区位熵以 0.9 万元/人(陆域经济发展 水平)为分界点, 小于该值时对海洋经济效率呈显 著负影响, 大于该值时, 呈显著正影响; 海洋科研人 力资本以每 1000 个海洋从业人员中有 1.42 个海洋 科研人员为临界点, 当小于临界值时, 对海洋经济 效率影响系数显著为正, 当大于临界值时, 对海洋 经济效率提高作用不显著; 海洋环保技术水平以 0.46 为临界点存在单门槛, 小于 0.46 时, 对海洋经济 效率呈正影响, 大于 0.46 时, 影响不显著。陆域经 济发展水平、海洋产业结构水平、政府对海洋科技 支持力度、海洋经济政策力度对海洋经济效率呈显 著正影响,对外开放水平对其影响不显著。

\section{2 建议}

通过以上分析和结论, 对中国沿海各地区提出 针对性建议: 天津应抢抓京津冀协同发展、“一带一 路”建设和承建北方国际航运中心临港产业承载区 等战略机遇, 充分利用京津冀资本、技术、配套产 业, 同时也应在京津冀一体化过程中支持和帮扶河 北; 河北需加强同临近海洋强省天津和山东的交流 合作,引进先进经验及技术, 同时也应注意节能减 排, 优化产业结构, 发展海洋新兴产业, 增加海洋第 三产业比重; 辽宁应充分利用好振兴东北老工业基 地的国家政策, 发挥辽宁沿海经济带作为东三省对 外联系的门户优势, 同时注重海洋新兴产业发展, 做到 “在发展中保护, 在保护中发展”; 上海第三产 业中海洋科研教育、海洋科技服务、社会服务等比 例需要加强, 海洋基础管理有待加强; 江苏虽为经 济强省, 但海洋经济总量不高, 对经济贡献率较低, 需要科技含量高、引领作用强、经济总量大的项目 拉动支撑, 传统产业结构也需进一步调整, 做好陆 海统筹, 并充分利用位于长三角区位优势, 加强合作 交流; 浙江依托《浙江海洋经济发展示范区规划》[30] 加快建设“一个中心, 四个示范区”, 提高海洋新兴
战略性产业比重和科技转化率, 优化产业结构, 逐 渐改变传统劳动密集型海洋作业方式; 福建作为海 峡蓝色经济带, 不仅有区位优势, 且资源丰富,但产 业层次需要进一步提升, 海洋资源开发深度有待加 深, 海洋科技成果转化率和产业化有待加强; 山东 作为海洋经济强省, 继续发展优势产业, 加强港城 港陆协同,促进陆海产业融合发展, 为海洋经济基 础薄弱、资源利用率低的河北提供经验和支持,带 动北部海洋经济圈整体效率, 同时也应加强国际海 洋创新领域的交流合作,在南部海洋经济圈起到科 技引领作用; 广西虽然资源丰富,但需调整改善产 业结构,发展高科技产业和海洋新兴产业, 同时也 应充分利用好区位优势, 向广东借鉴学习; 海南继 续加强国际旅游岛建设,打造低碳海南,将生态优 势转化为经济优势, 并抓住 21 世纪海上丝绸之路建 设机遇, 发挥直接面向南海周边国家和 21 世纪海上 丝绸之路沿线国家的区位优势。

\section{3 不足与展望}

(1)本文基于考虑非期望产出的三阶段超效率 SBM-Global模型测算中国海洋经济效率,虽克服了 存在多个有效决策单元时无法对其进行进一步对 比分析的缺点,但其测算的只是参照同一前沿面的 各决策单元相对效率,而不是各决策单元自身绝对 效率,因而今后的研究中应全面分析决策单元的相 对效率和绝对效率, 从两个方面更准确深人分析其 效率情况,并提出对应措施。

(2)海洋经济对当今经济发展发挥不可忽视的 作用,海洋经济效率是反应海洋经济是否可持续发 展的重要指标,但在注重绿色经济和生态环境保护 的今天,绿色海洋效率和海洋生态效率方面相关研 究还相对空白,这也将是未来研究的重要方向。

\section{参考文献(References):}

[1] 狄乾斌, 刘欣欣, 曹可. 中国海洋经济发展的时空差异及其动态 变化研究 [J]. 地理科学, 2013, 33(12): 1413-1420. [Di Q B, Liu X X, Cao K. Spatial and temporal disparities of marine economic development and dynamic changes in China[J]. Geography Science, 2013, 33(12): 1413-1420. ]

[2] 张耀光, 魏东岗, 王国力, 等. 中国海洋经济省际空间差异与海 洋经济强省建设[J]. 地理研究, 2005, 24(1): 46-56. [Zhang Y G, Wei D L, Wang G L, et al. Analysis of interprovincial space differ- 
ence in marine economy and the building of marine economically strong provinces in China[J]. Geographical Studies, 2005, 24(1): 46-56.

[3] 国家发展改革委. 全国海洋经济发展 “十三五”规划[EB/OL]. (2017-05-04)[2018-08-31]. http: //www.ndrc.gov.cn/zcfb/zcfbghwb/201705/t20170512_847297.html. [National Development and Reform Commission. "13th Five-Year plan" for National Marine Economic Development[EB/OL]. (2017-05-04) [2018-08-31]. http: //www.ndrc.gov.cn/zcfb/zcfbghwb/201705/t20170512_847297. html. ]

[4] Tingley D, Pascoe S, Coglan L. Factors affecting technical efficiency in fisheries: stochastic production frontier versus data envelopment analysis approaches[J]. Fisheries Research, 2005, 73(3): 363376.

[5] 卢昆, 郝平. 基于 SFA 的中国远洋渔业生产效率分析[J]. 农业技 术经济, 2016, (9): 84-91. [Lu K, Hao P. Production efficiency analysis of SFA Chinese Pelagic Fisheries[J]. Agricultural Technology Economy, 2016, (9): 84-91.]

[6] Odeck J, Brathen S. A meta-analysis of DEA and SFA studies of the technical efficiency of seaports: a comparison of fixed and random effects regression models[J]. Transportation Research Part A: Policy and Practice, 2012, 46(10): 1574-1585.

[7] 于谨凯, 潘菁. 基于超效率 DEA-Malmquist 模型的我国海洋交 通运输业效率分析[J]. 海洋经济, 2015, 5(5): 3-12. [Yu J K, Pan Q. Efficiency analysis of China's marine transportation industry based on super efficiency DEA-Malmquist model[J]. Marine Economy, 2015, 5(5): 3-12. ]

[8] 李淑娟, 周珊. 滨海城市旅游发展效率时空分异与驱动因素研 究-以山东半岛蓝色经济区为例[J]. 中国海洋大学学报(社会科 学版), 2015, (4): 8-15. [ Li S J, Zhou S. Spatial and temporal differentiation and driving factors of tourism development efficiency in coastal cities-a case study of Shandong Peninsula Blue Economic Zone[J]. Journal of Ocean University of China (Social Science Edition), 2015, (4): 8-15. ]

[9] 钟敬秋, 韩增林. 中国滨海旅游业效率评价及时空演变分析[J]. 海洋开发与管理, 2016, 33(8): 8-16. [Zhong J Q, Han Z L. Efficiency evaluation and temporal spatial evolution of coastal tourism in China[J]. Marine Development and Management, 2016, 33(8): 8-16. ]

[10] DING L L, ZHENG H H, KANG W L. Measuring the green efficiency of ocean economy in China: an improved three-stage model [J]. Romanian journal of economic forecasting, 2017, 20(1): 5 - 22.

[11] 范斐, 孙才志, 张耀光. 环渤海经济圈沿海城市海洋经济效率的 实证研究 [J]. 统计与决策, 2011, (6): 119-123. [Fan F, Sun C Z, Zhang Y G. Empirical study on marine economic efficiency of coastal cities around Bohai economic circle[J]. Statistics and Decision, 2011, (6): 119-123. ]

[12] 赵林, 张宇硕, 焦新颖, 等. 基于 SBM 和 Malmquist 生产率指数 的中国海洋经济效率评价研究[J]. 资源科学, 2016, 38(3): 461475. [Zhao L, Zhang Y S, Jiao X Y, et al. An evaluation of Chinese marine economy efficiency based on SBM and Malmquist productivity indexes[J]. Resources Science, 2016, 38(3): 461-475. ]

[13] Fried H O, Lovell C A K, Schmidt S S, et al. Accounting for environmental effects and statistical noise in data envelopment analysis [J]. Journal of Productivity Analysis, 2002, 17(1): 157-174.

[14] Kaoru T. A slacks-based measure of efficiency in data envelopment analysis [J]. European Journal of Operational Research, 2002, 143(1): 32-41.

[15] 马占新. 数据包络分析模型与方法 [M]. 北京: 科学出版社, 2010. [Ma Z X. The Models and Methods on Data Envelopment Analysis [M]. Beijing: Science Press, 2010. ]

[16] 陈巍巍, 张雷, 马铁虎, 等. 关于三阶段 DEA 模型的几点研究 [J]. 系统工程, 2014, (9): 144-149. [Chen W W, Zhang L, Ma T $\mathrm{H}$, et al. Some research on the three stage DEA model [J]. Systems Engineering, 2014, (9): 144-149. ]

[17] Lefever D W. Measuring geographic concentration by means of the standard deviational ellipse [J]. The American Journal of Sociolo$g y, 1926,32(1): 88-94$.

[18] Hanse B E. Threshold effects in non-dynamic panels: estimation, testing, and inference[J]. Journal of Econometrics, 1999, 93(2) : $345-368$.

[19] 黄建欢, 杨晓光, 胡毅. 资源、环境和经济的协调度和不协调来 源-基于 CREE-EIE 分析框架[J]. 中国工业经济, 2014, (7): 1730. [Huang J H, Yang X G, Hu Y. The coordination and incongruous sources of resources, environment and economy based on CREE- EIE analysis framework [J]. China Industrial Economy, 2014, (7): 17-30. ]

[20] 盖美, 刘丹丹, 曲本亮. 中国沿海地区绿色海洋经济效率时空差 异及影响因素分析[J]. 生态经济, 2016, 32(12): 97-103. [Gai M, Liu D D, Qu B L. Analysis of spatial and temporal differences and influencing factors of green marine economic efficiency in China's coastal areas [J]. Ecological Economy, 2016, 32(12): 97-103. ]

[21] 张军, 吴桂英, 张吉鹏. 中国省际物质资本存量估计: 19522000[J]. 经济研究, 2004, (10): 35-44. [Zhang J, Wu G Y, Zhang J P. Estimation of inter provincial material capital stock in China: 1952-2000[J]. Economic Research, 2004, (10): 35-44. ]

[22] Young A. Gold into Base Metals: Productivity Growth in the People's Republic of China during the Reform Period[R]. Beijing: National Bureau of Economic Research, 2000.

[23] 国家海洋局. 中国海洋统计年鉴[M]. 北京: 海洋出版社, 20002015. [State Oceanic Administration. China Marine Statistical Yearbook [M]. Beijing: Ocean publishing house, 2000-2015. ]

[24] 中华人民共和国环境保护部. 中国环境统计年鉴[M]. 北京: 中 国环境年鉴出版社, 2000-2015. [Ministry of Environmental Protection of the People's Republic of China. China Environmental Statistics Yearbook [M]. Beijing: China Environmental Yearbook Press, 2000-2015.

[25] 国家统计局. 中国统计年鉴[M]. 北京: 中国统计出版社, 20002015. [State Statistical Bureau. China Statistical Yearbook [M]. Beijing: China Statistics Publishing House, 2000-2015. ] 
[26] 国家统计局. 中国区域统计年鉴[M]. 北京: 中国统计出版社, 2000-2015. [ State Statistical Bureau. China Regional Statistical Yearbook [M]. Beijing: China Statistical Publishing House, 20002015.]

[27] 国家统计局城市社会经济调查司. 中国城市统计年鉴[M]. 北 京: 中国统计出版社, 2000-2015. [Department of Urban Social and Economic Investigation, National Bureau of Statistics. China Urban Statistics Yearbook [M]. Beijing: China Statistics Publishing House, 2000-2015.]

[28] 国务院. 关于实施东北地区等老工业基地振兴战略的若干意见 [EB/OL]. (2016-04-26)[2018-08-31]. http: //www.gov.cn/zhengce/ 2016-04/26/content_5068242.htm. [The State Council. Some Opinions on Implementing the Strategy of Revitalizing Old Indus- trial Bases in Northeast China[EB/OL]. (2016-04-26)[2018-0831]. http: //www.gov.cn/zhengce/2016-04/26/content_5068242.htm. ]

[29] 天津市海洋局. 天津市科技兴海行动[EB/OL]. (2016-08-10) [2018-08-31]. http: //www.tjoa.gov.cn/content.aspx?id=839281101536. [Tianjin Ocean Bureau. Tianjin Science and Technology to Promote the Sea Action[EB/OL]. (2016-08-10)[2018-08-31]. http: // www.tjoa.gov.cn/content.aspx?id=839281101536. ]

[30] 国家发展改革委. 浙江海洋经济发展示范区规划 [EB/OL]. (2011-03-12)[2018-08-31]. https: //baike.so.com/doc/84083198728034.html. [National Development and Reform Commission. Zhejiang Marine Economic Development Demonstration Zone Planning[EB/OL]. (2011-03-12)[2018-08-31]. https: //baike.so. com/doc/8408319-8728034.html. ]

\title{
Spatio-temporal evolution and influencing factors of marine economic efficiency in coastal areas of China
}

\author{
GAI Mei, ZHU Jingmin, SUN Caizhi, SUN Kang \\ (Center for Studies of Marine Economy and Sustainable Development of Liaoning Normal University, Dalian 116029, China)
}

\begin{abstract}
Based on the three stage super-efficient SBM-Global model, standard deviation ellipse and centroid coordinate method, the marine economic efficiency of 11 coastal provinces and cities of China in 2000-2015 years is calculated and analyzed with the time and space. Research discovery: (1) Compared with the first stage, the efficiency of marine economy in the third stage has increased overall, and the ranking of provinces and cities has changed differently. (2) In the evolution of time: The efficiency of marine economy in all coastal areas of China has been on the rise, and the absolute and relative difference has been increasing and the relative difference changes relatively smooth. (3) In space evolution: The national standard deviation ellipse was distributed in the Northeast- Southwest pattern and its area increased from small to large. The efficiency distribution changes from the contraction trend to the dispersion trend and finally in the three level pattern of North, Middle and South, which is in accordance with the three major marine economic circles. The standard deviation ellipse area of the three major marine economic circles is gradually reduced, and polarization appears in the efficiency distribution. (4) There is a nonlinear relationship between development level of land area economy, marine economic location entropy, human capital of marine scientific research, marine environmental protection technology level and marine economic efficiency; land economic development level, the level of marine industrial structure, the government's support for marine science and technology has a significant positive impact on it, and the level of opening to the outside world has no significant impact on it.
\end{abstract}

Key word: marine economic efficiency; three stage super efficiency SBM-Global; standard deviation ellipse; center of gravity transfer; panel threshold model; coastal areas; China 